\title{
AIKUISTEN TURVAPAIKANHAKIJA- JA PAKOLAISASIAKKAIDEN TERAPEUTTISISSA KESKUSTELUISSA TEKEMÄT ONGELMANMÄÄRITTELYT
}

\section{Johdanto}

Erilaiset ongelmat saavat turvapaikanhakijat ja pakolaiset hakemaan terapeuttista keskusteluapua. Sen selvittämistä ja ymmärtämistä, kuinka turvapaikanhakija- ja pakolaisasiakkaat ongelmansa itse kokevat, on pidetty keskeisenä lähtökohtana terapeuttisiin keskusteluihin (esim. Murray ym. 2010). Tässä tutkimuksessa tarkastellaan, kuinka aikuiset turvapaikanhakija- ja pakolaisasiakkaat kuvaavat ongelmiaan terapeuttisissa keskusteluissa. Tutkimuksen kohteena ja tiedon lähteenä ovat asiakkaiden tekemät ja tulkkien suomeksi välittämät, ongelmia kuvaavat ilmaukset. Tulkkia käytetään kielellisen vuorovaikutuksen mahdollistajana keskusteluissa silloin, kun asiakkaalla ja työntekijällä ei ole yhteistä kieltä (Tribe \&t Lane 2009).

Turvapaikanhakijoiden ja pakolaisten ongelmia on tutkittu erityisesti selvittämällä traumaperäisen stressihäiriön, masennuksen ja ahdistuneisuuden esiintyvyyttä (Craig 2010; Snellman ym. 2014). Esimerkiksi Elsing (2017) on tutkinut Suomessa olevien turvapaikanhakijoiden kokemien masennus- ja ahdistuneisuusoireiden esiintyvyyttä. Esiintyvyyteen liittyvä tutkimus on hyödyllistä, mutta siihen liittyy myös ongelmia ja se jättää ongel- mien käsitteellistämiseen ja ymmärtämiseen katvealueita (Miller ym. 2006). Esimerkiksi esiintyvyystutkimuksissa käytettävien länsimaisten diagnoosijärjestelmien suora sovellettavuus muunlaisista kulttuureista tulevien ihmisten kohdalla on ongelmallista (Alarcón 2014). Oireet eivät ehkä esiinny turvapaikanhakijoilla ja pakolaisilla samalla tavalla kuin diagnoosijärjestelmissä on määritelty (Hinton Ct Kirmayer 2013), ja heillä voi lisäksi olla aivan erityisiä kulttuurisidonnaisia ongelmia (Kirmayer 2005). Yleisesti ongelmien tarkastelu vain oirelistojen avulla ja näiden tulosten yhteen summaaminen antaa ongelmista varsin kapea-alaisen kuvan (Fava \& Sonino 2010). Oireet eivät esimerkiksi kerro suoraan siitä, miten ihmiset ongelmansa ymmärtävät, millaisia merkityksiä he ongelmalleen antavat, miten he ongelmaansa suhtautuvat tai miten he ongelman kanssa toimivat (Kleinman ym. 1978). Terapeuttisissa keskusteluissa taas käsitellään keskeisesti juuri näitä yksilöllisiä kokemuksia, tulkintoja ja jäsennyksiä ongelmista (Wampold 2007).

Kleinman ja kumppanit (1978) ovat esittäneet jo liki neljäkymmentä vuotta sitten lähestymistapaa, joka tarkastelee ongelmiin liitettyjä kokemuksia, tulkintoja ja jäsennyksiä 
selitysmallien (explanatory models) kautta. Selitysmallit ovat ihmisten ongelmiin liittämiä käsityksiä, ideoita ja uskomuksia (Weiss et Somma 2007). Ne ovat tapoja, joilla ihmiset ongelmia jäsentävät ja sanallisesti kuvaavat (Helman 2004). Selitysmalleihin liittyvää lähestymistä voi kuvailla etnografisesti suuntautuneeksi tarkasteluksi asiakkaan "paikallismaailmasta"; siitä, miten hän ongelmia tulkitsee ja jäsentää, sekä siitä, mitä hän avulta odottaa ja toivoo (Kleinman \& Benson 2006).

Kleinman ja kumppanit (1978) ovat määritelleet selitysmalleja selvittämään kahdeksan konkreettista kysymystä, joita työntekijä voi asiakkaalle esittää. Asiakkaalta kysytään, mitä ongelmia on, mikä on ongelmat aiheuttanut, miksi ongelmat alkoivat silloin kun alkoivat, miten ongelmat vaikuttavat, miten vakavia ongelmat ovat, minkälaista apua ongelmiin pitäisi saada, mitä avun pitäisi ongelmien osalta tuottaa ja mitä pelättävää ongelmissa on. Osa kysymyksistä koskee ongelmaa ja osa sitä, mikä ongelman osalta auttaisi. Kysymysten aiheisiin, sanamuotoihin ja määrään on sittemmin esitetty myös muunlaisia mallinnuksia ja tehty uusia kysymyslistoja (esim. Weiss 1997). Esimerkiksi Bettman ym. (2015) ovat tutkineet somalitaustaisten pakolaisten ongelmiin ja auttaviin asioihin liittämiä selitysmalleja. Heidän selitysmallinsa erosivat huomattavasti tyypillisistä länsimaisista selitysmalleista.

DSM-5-diagnoosijärjestelmän kulttuurisen diagnostisen haastattelun ohjeistuksissa painotetaan selitysmallien selvittämisen tärkeyttä (Lewis- Fernández ym. 2016). Samoin ajankohtaisissa suosituksissa painotetaan asiakkaan kulttuurin huomioivaa terapeuttista keskusteluapua (esim. Hinton \&t Jalal 2014). Esimerkiksi Benishin ym:iden (2011) mukaan keskeistä vaikuttavassa, asiakkaan kulttuurin huomioivassa terapeuttisessa keskusteluavussa on asiakkaan ongelmaan liittämien selitysmallien tarkastelu, niistä ja työntekijän selitysmalleista tapahtuva neuvottelu sekä vähemmän ongelmallisten selitysmallien aikaansaaminen asiakkaalle.

Turvapaikanhakija- ja pakolaisasiakkaiden ongelmakuvauksia on aiemmin tutkittu selitysmalleja tarkastelevan lähestymistavan kautta vain muutamissa terapeuttisen keskusteluavun jälkeisissä haastattelututkimuksissa (esim. Maier \&t Straub 2011). Suomessa ei tutkimuksia ole tehty. Tutkimustiedon vähäisyyden, ymmärryksen lisäämisen ja terapeuttisen keskusteluavun kehittämisen kannalta aihetta on syytä tutkia lisää. Tässä tutkimuksessa ongelmakuvauksia tarkastellaan luonnollisista terapeuttisista keskusteluista kolmen Kleinmanin ja kumppanien (1978) määrittelemän, selitysmalleja selvittävän kysymyksen aiheen osalta. Tutkimuksen tarkoituksena on kuvata asiakasosallistujien selitysmalleja ensisijaisesti sen osalta, mitä ongelmia heillä on, ja lisäksi sen osalta, miten nämä ongelmat heihin vaikuttavat ja mikä ongelmat aiheuttaa.

\section{Menetelmä}

Tutkimus on osa väitöstutkimusta, jossa tarkastellaan Suomessa oleville aikuisille turvapaikanhakijoille ja pakolaisille järjestettävää terapeuttista keskusteluapua. Tutkimus on toteutettu Suomen Mielenterveysseuran ylläpitämässä kriisikeskuksessa Helsingissä. Suomen Mielenterveysseuran maahanmuuttajien kriisipalvelut ovat toimineet Helsingissä vuodesta 1989 alkaen, ja asiakkaita on tänä aikana ollut tuhansia yli sadasta maasta (Haavikko Et Bremer 2009).

\section{Terapeuttinen keskusteluapu}

Haavikko ja Bremer (2009) ovat määritelleet kriisikeskuksessa maahanmuuttajataustaisten asiakkaiden kanssa tehtävän keskusteluavun terapeuttiseksi keskusteluksi, jossa asiakas pohtii yhdessä työntekijän kanssa elämäntilannettaan ja he etsivät yhdessä tapaa helpottaa asiakkaan oloa. Keskusteluapu on lähtökohtaisesti lyhytkestoista kestäen yhdestä kymmeneen tapaamiskertaan. Keskustelukäynnit ovat asiakkaalle maksuttomia. Kriisikeskuksessa tehtävään keskusteluapuun ei ole käsikirjaa, jossa olisi tarkasti määritelty käytettävät hoidolliset elementit, tekniikat ja työmenetelmät. Keskusteluapua tässä tutkimuksessa tarjosivat kolme kriisikeskuksessa 
kriisityöntekijän nimikkeellä työskentelevää työntekijää. Jokaisella heistä oli psykoterapeuttikoulutus ja psykoterapeutin ammattinimikkeen käyttöoikeus. Tässä tutkimuksessa keskusteluavun sisältöön ei annettu ohjeita eikä työntekijöillä ollut tietoa tutkimuksessa tarkasteltavista asioista.

\section{Asiakkaat}

Tutkimuksen asiakasosallistujina oli kuusi kriisikeskuksesta apua hakenutta aikuista turvapaikanhakijaa tai pakolaista. Terapeuttisen keskusteluavun alkaessa asiakkaista kolme oli turvapaikanhakijoita ja kolme pakolaisia. Pakolaisella on oleskelulupa ja turvapaikanhakijalla ei ole. Kaikki asiakkaat olivat alun perin tulleet Suomeen turvapaikanhakijoina.

Taulukko 1. Tutkimuksen asiakasosallistujien sukupuoli, ikäluokka ja oleskelustatus.

\begin{tabular}{|l|l|l|}
\hline Nainen & 20-30 vuotta & Turvapaikanhakija \\
\hline Nainen & 45-55 vuotta & Turvapaikanhakija \\
\hline Mies & 25-35 vuotta & Turvapaikanhakija \\
\hline Mies & $40-50$ vuotta & Pakolainen \\
\hline Mies & 55-65 vuotta & Pakolainen \\
\hline Mies & $60-70$ vuotta & Pakolainen \\
\hline
\end{tabular}

Asiakkaat olivat eri maiden kansalaisia. Kaksi asiakkaista oli lähtöisin Lähi-idän alueelta. Pohjois-Afrikan, Länsi-Afrikan, KeskiAfrikan ja Venäjän federaation alueelta oli kustakin yksi asiakas. Asiakkaista neljä oli miehiä ja kaksi naisia. Asiakkaiden ikärakenne vaihteli nuoresta aikuisesta eläkeikäiseen. Asiakkuuden alkaessa he olivat viettäneet Suomessa eripituisia aikoja, kaikki kuitenkin alle viisi vuotta. Koulutustaustat vaihtelivat suuresti kouluja käymättömästä akateemisen koulutuksen saaneeseen. Osa oli Suomessa yksin ja osa eli parisuhteessa. Ansiotyössä asiakkaista ei ollut kukaan, mutta puolet oli jossain vaiheessa asiakkuuttaan ollut jonkinlaisessa koulutuksessa. Kaksi asiakasta asui turvapaikanhakijoiden vastaanottokeskuksessa ja muut yksityisasunnoissa.

Kaikki tutkimuksen asiakasprosessit toteu- tuivat vuosien 2011-2014 aikana. Tutkimuksen alkuperäinen asiakaskriteeri oli maahanmuuttajataustaisuus, mitä tarkennettiin turvapaikanhakijoihin ja pakolaisiin. Tutkimukseen tuli mukaan kuusi asiakasosallistujaa, jotka jakaantuivat tasan kolmen työntekijäosallistujan kesken. Muita kriteereitä ei ollut käytössä, ei esimerkiksi jonkinlaista raja-arvoa jollakin psyykkistä hyvinvointia mittaavalla arviointimenetelmällä. Tällaiset arviointimenetelmät eivät ole osa normaalikäytäntöä kriisikeskuksessa.

Artikkelin ensimmäinen kirjoittaja oli sopinut työntekijöiden kanssa, että he kertovat ensimmäisellä käyntikerralla kaikille kriteerit täyttäville asiakkaille tutkimuksesta ja kysyvät halukkuutta osallistua siihen. Asiakkaille kerrottiin esimerkiksi kriisikeskuksesta, anonymiteetistä, osallistumisen vapaaehtoisuudesta ja siitä, että kieltäytyminen ei vaikuta saataviin palveluihin. Tämä ei kuitenkaan toteutunut täysin näin. Työntekijät eivät kertoneet tutkimuksesta kaikille asiakkaille. Tutkimukseen osallistuminen oli työntekijöille uusi kokemus ja asiakkaille kertomista arasteltiin. Niistä asiakkaista, joille kerrottiin tutkimuksesta, osa suostui mukaan ja osa ei. Kaikilta kuudelta tutkimuksessa mukana olleelta asiakasosallistujalta saatiin lupa videotallentaa heidän käyntinsä työntekijöiden luona sekä käyttää heidän aineistojaan tässä tutkimuksessa. Tutkimukselle oli myös Suomen Mielenterveysseuran myöntämä lupa.

\section{Aineisto}

Tutkimusaineiston muodostaa edellä kuvattujen kuuden asiakkaan videonauhoitetut terapeuttiset keskustelukäynnit työntekijöiden luona. Käynnit nauhoitettiin toisesta käyntikerrasta lähtien. Käynnit olivat yleisesti noin tunnin mittaisia. Kaikki keskustelut käytiin tulkkien välityksellä. Kaikista videotallenteista litteroitiin suomeksi sanottu puhe sanatarkasti kirjalliseen muotoon. Noin puolet puheesta tapahtui asiakkaan äidinkielellä, joka jäi litteroimatta. Yhteensä litteroitua tekstiä muodostui 320 sivua.

Terapeuttisen keskustelun käyntien mää- 
rässä ja tiheydessä sekä prosessin kestossa oli asiakkaiden välillä vaihtelua. Nauhoitettujen käyntien määrä vaihteli 8 ja 18:n välillä. Yhteensä nauhoitettuja käyntejä oli 70. Käyntikertoja oli pääsääntöisesti kerran viikossa, tosin kahdessa asiakasprosessissa käynnit toteutuivat keskimäärin 3 - 4 viikon välein. Lyhyimmillään asiakasprosessi kesti noin kolme kuukautta ja pisimmillään lähes vuoden.

\section{Analyysimenetelmä}

Tutkimuksessa käytetty aineiston analyysimenetelmä on aineistolähtöinen laadullinen sisällönanalyysi (esim. Mayring 2000; Elo Ct Kyngäs 2008). Sisällönanalyysi valikoitui analyysimenetelmäksi, koska tutkimuksen tavoitteena oli tarkastella ja kuvata aihetta tiiviissä ja yleisessä muodossa. Tutkimuksen kohteena olevat aiheet ohjasivat analyysia, ja analyysi eteni induktiivisesti alhaalta ylöspäin (esim. Mayring 2000). Analyysiyksiköt muodostettiin aineistosta. Sisällönanalyysin teki artikkelin ensimmäinen kirjoittaja. Erityisiä ennakko-oletuksia sille, mitä ongelmat voisivat olla, ei ollut.

Selitysmalleja tarkasteleva lähestymistapa (Kleinman ym. 1978) ei määrittele sitä, mitä analyysissä voitaisiin hyväksyä ongelmaa kuvaaviksi ilmaisuiksi. Yleisesti asiakasosallistujien ongelmat olivat niitä asioita, jotka saivat heidät hakemaan apua kriisikeskuksesta ja käymään keskustelukäynneillä. Aineistosta ongelmaa kuvaaviksi ilmaisuiksi hyväksyttiin ne ilmaukset, joissa asiakasosallistujat kuvasivat vaikeuksia, tyytymättömyyttä, kärsimystä tai pahoinvointia. Analyysissa kiinnitettiin huomiota ilmaisujen asiayhteyteen ja ajatuskokonaisuuteen. Esimerkiksi yksittäistä ongelmaa kuvaavaa sanaa tai lausetta ilman asiayhteyttä ja ajatuskokonaisuutta ei sellaisenaan hyväksytty ongelmaa kuvaavaksi ilmaisuksi, mutta ne auttoivat tavoittamaan aineistosta näiksi hyväksyttyjä kokonaisuuksia. Tämä on myös selitysmalleja tarkastelevan lähestymistavan perusajatus (Kleinman ym. 1978)

Kun ongelmiksi määriteltävissä olevat ilmaukset oli poimittu erikseen, niitä ryhmiteltiin sen mukaan, mitä ongelma koski. Sa- malla ongelmien alle ryhmiteltiin kuvauksia niiden aiheuttajista ja seuraamuksista. Näitä kaikkia oli usein mukana samoissa kuvauksissa. Ryhmittelyssä ongelmia kiteytettiin keskeisiksi ongelmakategorioiksi ja kategoriat nimettiin sisältöä kuvaavasti. Tehtyjä tulkintoja arvioitiin säännöllisesti. Kriteerinä keskeisten ongelmakategorioiden muodostamisessa oli myös ongelman yleisyys. Kategorian kriteerinä oli sen esiintyminen yli puolella asiakasosallistujista. Kaikilla asiakasosallistujilla ei edellytetty olevan ongelmaa.

Yleinen havainto oli, että ongelmapuhe muodosti suuren osan keskusteluiden sisällöstä ja että työntekijän kysyessä ongelmista asiakasosallistujat ymmärsivät hyvin, mitä heiltä kysyttiin ja mihin heidän pitäisi vastata. Ongelmakuvaukset eivät kuitenkaan lähteneet liikkeelle vain työntekijän kysymyksistä. Valtaosa asiakkaista osasi tuoda ongelmia esiin oma-aloitteisesti. Asiakkaiden ongelmat myös elivät ja muuttuivat asiakasprosessin aikana. Esimerkiksi asiakkaan käyntien aikana saamat ikävät kuulumiset kotimaasta tulivat poikkeuksetta mukaan keskusteluihin. Asiakas saattoi myös rohkaistua vasta useamman käyntikerran jälkeen kertomaan kotimaassaan mahdollisesti kokemastaan väkivallasta. Ongelmakuvaukset oli siten siivilöitävä koko asiakasprosessin ajalta.

Havaittiin myös, että asiakkailla oli vaihtelevia tapoja puhua ongelmista. Samantyyppistä ongelmaa saatettiin kuvailla erilaisilla tavoilla, mikä vaikeutti joidenkin ilmausten ryhmittelyä tiettyyn kategoriaan. Kotimaassa koettuja ongelmia kuvaavat ilmaukset olivat haastavimpia ryhmitellä. Arkisempien väärinkohtelun ja epäoikeudenmukaisuuden sekä erityisempien traumaattisten tilanteiden ja kokemusten ryhmittely oli haastavaa. Kun esimerkiksi eräs asiakas kuvasi kidutukseksi sitä, että hän menetti valtaapitävien takia työpaikkansa, menetystä ei vain kidutus-sanan käyttämisen takia määritelty traumaattiseksi kokemukseksi, vaan se tulkittiin arkisemmaksi väärinkohtelun kokemukseksi. Joissain tapauksissa olisi myös ollut liian kapea-alaista tarkastella vain asiakkaan ilmaisujen sisältöä. Esimerkiksi erään asiakkaan oli hyvin vaikea puhua prostituu- 
tioon pakottamisesta ja siihen liittyvästä syvästä häpeästä. Tällöin valtaosa kuvauksesta oli työntekijän kysymyksissä ja muotoiluissa, jotka asiakas vahvisti myöntävillä äännähdyksillä ja muilla lyhyillä vastauksilla, kuten "joo" tai "kyllä". Tämä olisi jäänyt määrittelemättä ongelmakuvaukseksi, mikäli työntekijän ilmaisut olisi jätetty huomiotta.

Asiakkaiden ongelmien kuvaukset saattoivat olla selkeitä ja konkreettisia mutta myös koko elämään ja pakolaisuuteen liittyviä prosessikuvauksia. Esimerkiksi asiakkaan kuvaamalle avuttomuuden tunteelle, kun hän ei päässyt kielikurssille, on helppo määritellä oma ongelmakategoriansa. Enemmän tarkastelua ja tulkintaa vaatii saman asiakkaan koko asiakasprosessin ajan esittämä kuvaus yli 15 vuotta kestäneestä ja monia elämänvaiheita ja tekijöitä sisältäneestä väärinkohtelusta.

\section{Tulokset}

Analyysin perusteella syntyi viisi ongelmakategoriaa. Ongelmakategoriat nimettiin seuraavasti sen mukaan, mitä ongelman ensisijaisesti identifıoitiin koskevan: 1) kotimaassa koettu epäoikeudenmukaisuus, 2) kotimaassa koettujen traumaattisten kokemusten aiheuttama ahdistus, 3) tulevaisuuteen liittyvät huolet ja pelot, 4) huoli läheisten tilanteesta ja siihen liittyvä syyllisyys ja 5) toimijuuden, pystyvyyden ja elämänhallinnan ongelmat.

Kategoriat esitellään aineistosta poimittujen tekstinäytteiden avulla. Tekstinäytteillä pyritään kuvaamaan myös sitä, mikä ongelman aiheuttaa ja millaisia seuraamuksia ongelmalla on. Näytteistä on poistettu kaikki asiakkaiden tunnistamisen mahdollistavat tiedot. Näytteisiin on merkitty sukupuoli ja ikäluokka. Katkelmissa viitataan asiakkaaseen lyhenteellä A ja työntekijään lyhenteellä T sekä asiakkaan kotimaahan lyhenteellä XX. Merkintä - - tarkoittaa, että näytteestä on jätetty osa pois.

\section{Kotimaassa koettu epäoikeudenmukaisuus}

Tähän kategoriaan sisällytettiin ilmaukset, joissa kuvattiin epäuskoa kotimaan valtaapitävien toimintaa kohtaan, petetyksi ja vää- rinkohtelun uhriksi joutumista, kotimaan menettämistä sekä näistä johtuvaa pettymystä, katkeruutta sekä luottamuksen menettämistä asioiden järjestymiseen. Kaikki asiakasosallistujat ilmaisivat ongelman.

Kielteistä kokemusta kotimaassa vallitsevista epäkohdista leimasi totaalisuus. Näistä oli asiakkaiden puheessa monenlaisia toisiinsa liittyviä kuvauksia.

”Siellä on vähän erilaista kuin täällä, siellä on vaikeaa. Siellä on korruptiota, terrorismia, räjähdyksiä. Pitäis järjestää koko yhteiskunta uudestaan.” (Mies, 55-65.)

"Yhä enemmä ihmisiä pakenee sieltä ku he eivät kestä sitä pelkoo. Siellä on täydellinen mielivalta." (Mies, 60-70.)

Kotimaan epäkohdat yhdistyivät asiakkaiden kuvauksissa omakohtaisiin kokemuksiin väärinkohtelusta ja epäoikeudenmukaisuudesta. Asiakkaat kertoivat konkreettisia esimerkkejä kokemistaan menetyksistä, petetyksi tulemisesta ja kokemastaan asiattomasta kohtelusta kotimaan valtaapitävien taholta. Erityisen vaikeaa oli ymmärtää sitä, että maanmiehet saattoivat tuhota kotimaan ja että oman kodin ja kotimaan menetti maanmiesten oikeudettoman toiminnan johdosta. Menetys näyttäytyi laajempana "kulttuurisena menetyksenä", johon sisältyvät fyysisen kodin menettämisen lisäksi esimerkiksi identiteetin, sosiaalisten rakenteiden ja kulttuurin menetykset (esim. Eisenbruch 1990).

"Tiedätkö että XX:ssa minulta vietiin kaikki oikeudet, en saanut tehdä työtä. Epäoikeudenmukaisuus on kaikkialla XX:ssa." (Nainen, 45-55.)

Moni kertoi kokevansa pettymystä, katkeruutta ja jopa vihaa kotimaansa vallanpitäjiä kohtaan. Vallanpitäjien tekoja kotimaata kohtaan ja itselle tapahtuneita asioita oli vaikeaa tai mahdotonta unohtaa, hyväksyä tai antaa anteeksi.

"Kyllä minulla on vihaa maani vallan- 
pitäjiä kohtaan. Jos tulisi mahdollisuus osallistua aseelliseen kapinaan heitä kohtaan, en hetkeäkään epäröisi osallistua." (Mies, 40-50.)

Asiakkaat kertoivat seuraavansa kotimaan tilannetta ja tapahtumia herkeämättä erilaisten medioiden kautta. Asioista myös juteltiin säännöllisesti Suomessa olevien maanmiesten ja mahdollisten perheenjäsenten kanssa. Tilanteen jatkuva seuraaminen ylläpiti ja vahvisti ongelmallista kokemusta, mutta sitä oli vaikea lopettaa tai edes vähentää.

T: "Joskus sanotaan, että kun kaukaa seuraa, niin voi olla hieman ylikierroksilla asian suhteen."

A: "Se on kyllä totta." (Mies, 40-50.)

Myönteistä muutosta kotimaassa toivottiin, mutta erityisesti itselle tapahtuneet koettelemukset olivat poistaneet uskon ja luottamuksen sen toteutumiseen.

"- - mäkin saattasin vielä ajatella XX:ssa voi jotain hyvää tehdä, siellä voi jotaki tehdä, elää normaalisti, mut sen jälkeen mitä he minulle tekivät, en pysty ajattelemaan niin. Ei kerta kaikkiaan voi luottaa." (Mies, 60-70.)

\section{Kotimaassa koettujen traumaattisten} kokemusten aiheuttama ahdistus

Kotimaassa koettujen traumaattisten kokemusten aiheuttaman ahdistuksen ongelmiin luokiteltiin ilmaukset, jotka liittyivät kotimaassa koettujen ikävien tilanteiden ja niihin liittyvien muistojen ja tunteiden säännölliseen mieleen palautumiseen. Nämä ajatukset tuottivat ahdistusta, turvattomuutta ja pelkoa. Lisäksi ajatuksia oli vaikea hallita myönteisellä tavalla, mikä lannisti asiakkaita. Neljä asiakasosallistujaa kuvasi ongelman.

Ahdistavista ajatuksista ja niitä aiheuttavista tilanteista oli asiakkaiden puheessa monenlaisia kuvauksia. Ahdistavat ajatukset liittyivät johonkin kotimaassa koettuun konkreettiseen, epämieluisaan tilanteeseen tai ta- pahtumaan ja olivat psyykkisesti hankalia tai sietämättömiä. Näiden tilanteiden ja tapahtumien sekä niiden aikana koettujen ikävien tuntemusten palautuminen mieleen nykyhetkessä olivat tämän ongelman ilmentymiä.

"Sillon ku mä istuin siellä vangittuna, nii siellä oli niinku se painostus, kidutus. Yleensä se oli aina illalla ja yöllä, et päivällä sitä vaan pelkäs ja odotti - - . He saivat he ihmiset siihe tilaan, et alkoi jo toivoa että tappasivat nopeammi. Ja viimeset päivät enne ku pääsin vapaaks, mä oli jo iha varma että tulen hulluks.” (Mies, 60-70.)

Aiemmin koetut epämieluisat tilanteet ja tapahtumat olivat paikoin liian pelottavia tai hävettäviä. Esimerkiksi yksi naisasiakkaista oli ennen Suomeen tuloaan joutunut pakotetuksi prostituutioon. Tapahtuneen käsittely saati siitä puhuminen oli ylivoimaista. Alla olevassa katkelmassa asiakkaan ongelmankuvaus näkyy erityisesti työntekijän puheenvuoroissa, jotka asiakas vahvistaa lyhyillä myöntävillä vastauksillaan:

T: "Oliko se niin, että sun piti tehdä kaikki mitä sulta pyydettiin? Että sä et voinut vaikuttaa?"

A: "Joo."

T: "Eli sä oot joutunu tekemään vaikka mitä?"

A: "Joo."

$\mathrm{T}$ : "Miten paljon tää asia on sun mielessä täällä? Kun se häpeän tunne..."

A: "Ehkä joka päivä." (Nainen, 20-30.)

Erityisen raskasta oli näiden ahdistavien ajatusten jatkuva pyöriminen mielessä. Niiltä ei juuri saanut rauhaa. Asiakkaat kokivat ajatusten vaivaavan ympäri vuorokauden ja myös unessa. Heidän oli vaikea nukahtaa ja usea näki säännöllisesti painajaisia vanhoista tapahtumista ja tilanteista. Tämä loi jatkuvaa stressiä ja turvattomuuden tunnetta.

"Ne toistuu jatkuvasti, varsinkin ne uhkaukset, joita olen joutunut kohtamaan sen kidutuksen yhteydessä ja sen alla. Uhka- 
uksista tulleet seuraamukset pyörii jatkuvasti mun mielessä. Tuntuu, että mä en ole enää ollenkaan rauhassa, mulla on jatkuva stressitila ja sitten kärsin unettomuudestakin." (Mies, 25-35.)

Asiakkaat pyrkivät aktiivisesti näiden ajatusten hallintaan ja työntämään niitä pois mielestä. Ajatukset aiheuttivat myös ärtymystä ja kyllästyneisyyttä. Muutama asiakas kertoi ajatelleensa vanhoja asioita jo tarpeeksi. Niiden hallinta ei kuitenkaan tarkoituksellisesti juuri onnistunut. Ne pysyivät poissa mielestä lähinnä silloin, kun asiakas teki jotain muuta ja "unohti" ajatella niitä. Epäonnistuminen ajatusten hallinnassa tuotti 'demoralisaatiota' (esim. Frank 1986): se lannisti asiakkaita ja tuotti pettymystä itseensä.

"Mä olen todellakin yrittänyt kiinnittää mun huomiota eri suuntaan, harhauttaa mun mieltä - - keskittyä johonkin erilaiseen asiaan. Lukenut vaikka kirjaa. Tekemään jotain, jonka avulla voisi miettiä jotain muuta. Mutta se ei ole onnistunut." (Mies, 25-35.)

"Se on sillo ku lähden jonnekin, hoidan jotakin asioita, tapaan joitaki. Sillon ne unohtuu ne asiat." (Mies, 60-70.)

\section{Tulevaisuuteen liittyvät huolet ja pelot}

Kolmanteen kategoriaan kuuluviksi luokiteltiin kuvaukset, joissa epävarmuus omasta kohtalosta ja oman elämän tulevaisuuden järjestymiseen liittyvät huoliajatukset pyörivät jatkuvasti mielessä aiheuttaen rauhattomuutta, turvattomuutta ja pelkoa. Viisi asiakasosallistujaa kertoi ongelmasta.

Ongelma kiteytyi asiakkaiden kuvauksissa epävarmuuteen siitä, miten itselle tulevaisuudessa käy ja vielä konkreettisemmin siihen, saako jäädä Suomeen. Tämän koettiin olevan elämän tai kuoleman kysymys. Oma elämä ja tulevaisuus olivat muiden ihmisten käsissä, eikä siihen koettu olevan mahdollista vaikuttaa. Seurauksena oli varmuuden, ennustettavuuden ja järjestyksen puuttuminen elämästä.
"Pelkään eniten, että on epäselvä tulevaisuus. Kohtaloani."

"Mutta ajattelen, että tulen hulluksi jos jatkan näitä ajatuksia."

"Olo on epävarma." (Nainen, 45-55.)

Asiakkaiden puheessa kuvautui 'ruminaation' kaltainen kielteinen ajatusvyyhti (esim. Smith \&t Alloy 2009). Asiakkaat kuvasivat tulevaisuuden pelkonsa ja huolensa sekä luottamuksen puuttumisen asioiden järjestymiseen johtuvan kotimaassa koetuista epäoikeudenmukaisuuden kokemuksista. Epävarmuudesta kertoivat turvapaikanhakijat ja jo oleskeluluvan saaneet asiakkaat.

"Vaikka todennäköisyys - - olisi ja mut käännytettäisiin olisi vain 1 prosentti, mutta silti jo tämä riittää että pelko kasvaa mielessä.” (Mies, 25-35.)

"Se on nyttenki, vaikka sain myönteisen päätöksen ja sitä kerran pidennettyki, nii se pelko on jääny. Ja koko ajan on sellane pelko siitä ja epävarmuus siitä että se perutaan vielä.” (Mies, 60-70.)

Pelko liittyi erityisesti mahdollisuuteen joutua palaamaan takaisin kotimaahan ja siellä joutumista uudelleen valtaapitävien huonon kohtelun uhriksi. Tällaisen pelon kokemisesta kertoivat juuri ne asiakkaat, jotka olivat kokeneet kotimaassaan epämieluisia tilanteita ja tapahtumia, kuten kidutusta tai muunlaista väkivaltaa.

"Mä luulen et mun tilaan vaikuttaa se ajatus, et jos joudun uudestaa heidän käsiin. et vaikka tavallaa ei oo sellaista vaaraa, nii siitä huolimatta alitajunnassa on pelko et joudun uudestaa heidän käsiin." (Mies, 60-70.)

Epävarmuus omasta kohtalosta näkyi myös asiakkaiden motivaatiossa ja vaikutti kielteisesti halukkuuteen tehdä asioita nykyhetkessä, jos asiakas kuitenkin joutuisi lähtemään Suomesta tai jokin asia menisi vikaan. Alla olevassa katkelmassa näyttäytyy jonkinlainen 
noidankehä: elämäntilanne lamaannuttaa ja saa luopumaan niiden asioiden tekemisestä ja yrittämisestä, jotka tuottaisivat myönteisiä vaikutuksia ja mielihyvää.

A: "Niin mut sitten pää ja mieli on siinä ajatuksessa, että lähden kohta Suomesta, ettei kannata."

T: "Niin se varmaan on."

A: "Minä ajattelen sitä vaan, et jos aloitan koulun ja joudun lähtemään, menee se hukkaan." (Nainen, 20-30.)

Huoli läheisten tilanteesta ja

siihen liittyvä syyllisyys

Tämän kategorian kuvauksiin sisältyi jatkuva huoli perheen turvallisuudesta ja selviytymisestä kotimaassa sekä tähän tilanteeseen liittyvä syyllisyys ja häpeä. Ongelma aiheutti jännittyneisyyttä ja pahoinvointia asiakkaissa. Kaikki asiakasosallistujat kuvasivat tämän ongelman.

Verrattuna tulevaisuuteen liittyvien huolien ja pelkojen ongelmakategoriaan huoliajatukset liittyivät tässä kategoriassa muihin ihmisiin ja tarkemmin ottaen omiin perheenjäseniin:

"Se on hermostuttava asia, kun toisaalta ajattelee, että kaikki menee hyvin ja toisaalta on pelko että ei. Todellakin he ovat riskialttiissa tilanteessa, se on kuin krokotiili joka voi haukata." (Mies, 40-50.)

Yhteydenpito kotimaassa oleviin perheenjäseniin toimi huolen kokemisen kannalta sekä myönteisesti että kielteisesti: sitä kautta saatu tieto vähensi epävarmuutta ja lisäsi hallinnan tunnetta, mutta tietoon tulleet mahdolliset ikävät kuulumiset lisäsivät huolta entisestään. Vaikka mitään erityisen ikävää ei olisi perheenjäsenille tapahtunut, yhteydenpito lisäsi asiakkaissa kuitenkin perheenjäseniä kohtaan tunnettua kaipuuta.

T: "Tänään vaikutatte hieman surumieliseltä. Onko se vain harhaa vai miltä tuntuu?" A: "Tytär, joka on XX:ssa, on soittanut."
T: "Tuliko ikävä?"

A: "Joo, paljonkin." (Nainen, 45-55.)

Koetun epävarmuuden, huolen ja jännittyneisyyden lisäksi asiakkaat ajattelivat, että heillä itsellään eivät asiat saisi olla yhtään paremmin kuin perheenjäsenillä kotimaassa eivätkä he tässä tilanteessa saisi "mennä eteenpäin" elämässä ja tavoitella mitään parempaa. Asiakkaat kertoivat tilanteesta kokemastaan syyllisyydestä. Syyllisyys johtui kuvauksissa siitä, että asiakas oli lähtenyt ja turvassa, mutta perheenjäsenet olivat jääneet ja asiakas oli jättänyt heidät vaikeisiin olosuhteisiin. Tästä kerrottiin sellaisella tavalla, joka ilmensi asian olevan hyvin vaikea ja arka. Tilanne ja oma toiminta aiheuttivat häpeää.

"Vaikea on syödä, jos lapset tulevat mieleen, jos on itse syömässä.” (Mies, 45-55.)

”Joo, painajaisia tulee. Ne valvottaa kyllä. Minä en voi unohtaa minun perheenjäsenet on vaarassa. Syyllisyydentunne ja keskittymättömyys johtuu näistä.” (Mies, 55-65.)

Asiakkailla oli tilanteen ja heidän oman toimintansa takia hyvin kielteinen käsitys itsestään. Syyllisyyden kokemuksesta oli vaikea puhua edes näissä luottamuksellisissa keskusteluissa. Se ei yleensä tullut esiin asiakkaiden kertomuksissa keskusteluapuprosessin alkuvaiheessa vaan vasta myöhemmillä käyntikerroilla. Vaikutti, että asiakkaat tällä tavoin halusivat suojella moraaliset "kasvonsa" ja säilyttää arvokkuutensa työntekijän edessä (esim. Ting-Toomey \& Kurogi 1998).

"Minusta tuntuu, että pelkurina olen lähtenyt." (Mies, 25-35.)

Toimijuuden, pystyvyyden ja elämänhallinnan ongelmat

Viidenneksi ja viimeiseksi kategoriaksi muodostui toimijuuden, pystyvyyden ja elämänhallinnan ongelmat. Tähän kategoriaan luokitelluissa ilmauksissa kuvattiin passiivisuutta ja kyvyttömyyttä muokata omia ajattelu- ja 
toimintamalleja sekä vaikeuksia viedä elämää haluttuun suuntaan nykyisessä elämäntilanteessa ja nykyisillä tiedoilla, taidoilla ja resursseilla. Tilanteessa koettiin avuttomuutta, väsymystä ja lannistumista. Kaikki asiakasosallistujat kuvasivat ongelman.

Ongelma kiteytyi asiakkaiden kuvauksissa kokemukseen siitä, että elämä menee eteenpäin eikä siihen ole mahdollisuutta vaikuttaa tai sitä hallita. Avuttomuuden ja lannistumisen kokemukset aiheuttivat ongelmaa ja olivat myös sen seurauksia. Ongelma esiintyi ajattelussa ja käytännön toiminnassa:

"Vähän kun katsoo telkkaria ja haluaisi muuttaa jotain mitä elokuvassa tapahtuu. Mutta kaukosäädin ei toimi. Minusta tuntuu että minun elämässä nämä kuvat menee vähän samalla tavalla. Ne vaan menee ja minä en pysty vaikuttamaan niihin." (Mies, 40-50.)

"- - mut nyt kun on sellaisessa odottavassa tilassa, niin että vaan syö ja nukkuu." (Nainen, 20-30.)

Asiakkaiden puheessa ongelma näyttäytyi toimijuuden ja pystyvyyden ongelmana (esim. Bandura 2001; Wahlström 2006): asiakkailla ei ollut mahdollisuuksia toimia tavoitteidensa suuntaisesti eikä heillä liioin ollut keinoja saavuttaa näitä tavoitteita. He eivät tehneet asioita, joita toivoivat tekevänsä, ja tekivät asioita, joita eivät toivoneet tekevänsä. Ongelman aiheuttivat samanaikaisesti asiakkaiden omat heikohkot edellytykset ja elämäntilanteen sekä uuden ympäristön olosuhteet. Kaikki asiakkaat kertoivat kuitenkin haluavansa vaikuttaa elämäänsä. Erään asiakkaan kuvaus "en haluaisi istua toimettomana" kiteytti hyvin näitä tuntoja. Käytännössä jo arjen perusasioissa pärjääminen saattoi olla asiakasosallistujille hankalaa:

T: "Sinne [hammaslääkäri] vois soittaa, mut mä mietin voidaanko me tästä mahdollisesti..."

A: "Mutta en minä osaa soittaa."

T: "Jo mä ajattelinki, et me voidaan tän tapaamisen päätteeks soittaa tänne ja sanoa että tarvitaan tulkki." (Mies, 55-65.)

Ongelmaan kuului myös kokemus siitä, että asiakas oli nyt Suomessa muiden avun varassa eikä itse kyennyt antamaan takaisin vaikka haluaisi. Tilannetta verrattiin omaan kotimaahan, jossa tällaista apua ei ollut saatavilla, ja aiempaan omaan identiteettiin toimijana ja aktiivisena yhteiskunnan jäsenenä. Eräs asiakas kuvasi itseään "elätiksi", joka identiteettinä tuntui hänestä vieraalta. Yhteiskunnalta saadusta avusta tunnettiin kiitollisuutta, mutta omasta vähäisestä panoksesta tunnettiin häpeää.

"- - mutta se tuntuu todella kiusalliselta, en minä en ole mitään muuta tälle yhteiskunnalle tällä hetkellä kuin liikaa taakkaa. Enkä pysty antamaan sitä takaisin." (Mies, 25-35.)

\section{Pohdinta}

Tutkimuksen kohteena olivat kuuden turvapaikanhakijan tai pakolaisen terapeuttiset keskustelut kriisikeskuksessa. Tutkimuksessa pyrittiin kuvaamaan asiakasosallistujien selitysmalleja ensisijaisesti sen osalta, mitä ongelmia heillä on, ja lisäksi sen osalta, miten nämä ongelmat heihin vaikuttavat ja mikä ongelmat aiheuttaa. Analyysin perusteella syntyi viisi ongelmakategoriaa.

Kotimaassa koettu epäoikeudenmukaisuus -kategoria sisältää ilmaukset, joissa kuvattiin epäuskoa kotimaan valtaapitävien toimintaa kohtaan, petetyksi ja väärinkohtelun uhriksi joutumista sekä kotimaan menettämistä. Jokainen asiakasosallistuja kuvasi ongelmaa, sen aiheuttajia ja seuraamuksia tavalla, joka on yhteneväinen yleisesti turvapaikanhakijoita ja pakolaisia yhdistävien, Papadopouloksen (2007) "yhteiskunnallisen trauman" sekä Nickersonin ja kumppaneiden (2015) "moraalisen vammautumisen" käsitteiden sisällön kanssa. Nickerson ja kumppanit (2015) toteavat moraalisen vammautumisen vaikuttavan vointiin jopa kielteisemmin kuin kotimaassa koettu väkivalta ja maahantulon jälkeiset on- 
gelmat yhteensä. Tällä tavoin petetyksi tuleminen oli erityisen raskas kokemus. Sitä oli vaikeaa tai mahdotonta unohtaa ja antaa anteeksi.

Kotimaassa koettujen traumaattisten kokemusten aiheuttama ahdistus -kategorian ilmaukset liittyivät kotimaassa koettujen ikävien tilanteiden ja niihin liittyvien muistojen ja tunteiden säännölliseen mieleen palautumiseen. Tämän kategorian ongelmassa, vaikutuksissa ja sen aiheuttavissa tekijöissä on yhteneväisiä piirteitä psyykkisen traumatisoitumisen kanssa (esim. Papadopoulos 2007). Kaikilla asiakasosallistujilla ei kuitenkaan ollut tämän kategorian ongelmaa. Niiden, joilla se oli, kertoman perusteella esimerkiksi kidutus (esim. Campbell 2007) on liian kapea-alainen lähtökohta lähestyä tätä ongelmaa aiheuttavia tekijöitä. Asiakkaat kertoivat myös muunlaisista ikävistä tilanteista. Havainto saa tukea Basoglun ym:iden (2007) tutkimuksesta, jossa vertailtiin kidutuksen vaikutusten eroja muunlaiseen julmaan ja halventavaan kohteluun. Heidän tutkimuksensa mukaan eroa ei juuri ollut ja myös muulla vastaavalla toiminnalla voi olla yhtäläisiä kielteisiä vaikutuksia. Tämän tutkimuksen asiakkaiden ongelmakuvausten sisällössä, määrässä, toistumisessa sekä voimakkuudessa oli myös huomattavaa vaihtelua. Esimerkiksi Cloitre (2015) on varoittanut niputtamasta samanlaisiksi kaikkia psyykkisesti traumatisoituneita henkilöitä.

Tulevaisuuteen liittyvät huolet ja pelot -kategorian ilmauksissa epävarmuus omasta kohtalosta ja oman elämän järjestymiseen liittyvät huoliajatukset pyörivät jatkuvasti asiakkaiden mielessä. Tämän on ajateltu olevan lähinnä turvapaikanhakijoiden ongelma (esim. Iversen ym. 2010). Ongelmaa ei niinkään ole yhdistetty pakolaisiin, koska oleskeluluvan myötä ongelman on ajateltu poistuvan. Ongelmasta kertoivat tutkimuksen kaikki turvapaikanhakija-asiakkaat ja kaksi pakolaisasiakkaista. Myös pakolaisasiakkaat kuvasivat ongelman aiheutuvan pelosta joutua takaisin kotimaahan. Aiemmat petetyksi tulemisen kokemukset vaikeuttivat luottamasta asioiden järjestymiseen. Pakolaistaustaisten ihmisten eniten toivomia asioita on tunne siitä, että on turvassa ja elämällä on tasaiset ja rauhalliset puitteet (esim. Ryan ym. 2008). Tämä ei täysin toteutunut tämän tutkimuksen asiakasosallistujilla.

Huoli läheisten tilanteesta ja siihen liittyvä syyllisyys -kategorian ongelman ilmaistiin johtuvan perheen tilanteesta kotimaassa. Kaikki asiakasosallistujat kuvasivat jatkuvaa huolta, mitä he kokivat perheensä turvallisuudesta ja selviytymisestä. Havainto saa tukea aiemmista tutkimuksista (esim. Bernardes ym. 2010), joiden mukaan huoli perheestä on yksi keskeisistä turvapaikanhakijoille ja pakolaisille pahoinvointia tuottavista asioista. Osa asiakkaista koki tilanteesta myös syyllisyyttä. Syyllisyyden ilmaistiin `selviytyjän syyllisyys' käsitteen (esim. Douglas 2010) mukaisesti johtuvan kokemuksesta, että oli itse lähtenyt ja turvassa, mutta perhe oli jäänyt tai jätetty vaikeisiin olosuhteisiin. Oma toiminta aiheutti asiakkaissa häpeää ja siitä oli vaikeaa puhua. Terapeuttiset keskustelut voivat olla erityistä toimintaa, joissa asiakas voi kertoa ja käsitellä tällaisia itselleen vaikeita asioita.

Viidenneksi kategoriaksi muodostui toimijuuden, pystyvyyden ja elämänhallinnan ongelmat. Kaikki asiakasosallistujat kuvasivat passiivisuutta ja kyvyttömyyttä muokata omia ajattelu- ja toimintamalleja sekä vaikeuksia viedä elämäänsä haluttuun suuntaan. Myös Snellman ym. (2014) ovat raportoineet tämänkaltaisista turvapaikanhakijoiden ja pakolaisten ongelmista. Turvapaikanhakija-asiakkaat kertoivat elämäntilanteen sisältävän paljon ulkoisia rajoitteita toimintamahdollisuuksille. Oleskelulupa poisti pakolaisasiakkailta näitä rajoitteita, mutta uusi tilanne toi mukanaan erilaisia ulkoisia rajoitteita, jotka vaikeuttivat toimintaa. Myös muissa maissa olevat pakolaiset ovat kertoneet samantapaisista elämän vaikeuksista oleskeluluvan saamisen jälkeen (esim. Strijk ym. 2011).

Patel ym. (2014) ovat esittäneet turvapaikanhakijoiden ja pakolaisten ongelmien olevan monenlaisia ja niiden kehittyvän usean tekijän yhteisvaikutuksesta. Myös Maierin ja Straubin (2011) tekemissä terapian jälkeisissä haastatteluissa turvapaikanhakija- ja pakolaisasiakkaat kuvasivat monenlaisia ongelmia. Nämä asiakkaat eivät ajatelleet ongelmiensa aiheutuvan vain yksittäisistä tilanteista 
tai vain joko kotimaassa tai maahantulon jälkeen koetusta. He kokivat ongelmiensa olevan monen tekijän summa. Tämä näkemys ja tutkimustulos saa tukea tästä tutkimuksesta. Esimerkiksi kaikkien tämän tutkimuksen asiakasosallistujien ongelmien koostumukset rakentuivat useammasta kuin yhdestä ongelmakategoriasta. Kaikki asiakkaat kertoivat ongelmista tavalla, joka ei puolla terapeuttiseen keskusteluun mallia, jossa keskityttäisiin kategorisesti vain joko aiemmin kotimaassa tai maahantulon jälkeen koettuihin asioihin.

Tämän tutkimuksen perusteella voidaan tehdä joitain suosituksia terapeuttisia keskusteluita turvapaikanhakija- ja pakolaisasiakkaiden kanssa käyvien työntekijöiden toimintaan. Ensinnäkin ongelmista tulisi puhua keskusteluissa. Vain sitä kautta voidaan saada ymmärrys asiakkaiden ongelmista ja heidän niihin liittämistä selitysmalleista. Tämän tutkimuksen asiakasosallistujat kertoivat ongelmista oma-aloitteisesti ja pääosin aktiivisesti. Tämä antaa viitteitä siitä, että he kokivat ongelmista kertomisen olevan jollakin tavalla hyödyllistä ja auttavaa. Ongelmapuheen aikaansaamisessa keskeistä näytti kuitenkin olevan työntekijän keskustelullinen aktiivisuus ja asiakkaan kokemus terapiasuhteen turvallisuudesta. Asiakasta ei kuitenkaan tulisi "pakottaa" kertomaan ylivoimaisilta ja liian vaikeilta tuntuvista asioista. Toiseksi johdannossa esitellyt Kleinmanin ja kumppanien (1978) määrittelemien selitysmalleja selvittävien kysymysten aiheet ja ajatus näiden kysymysten systemaattisesti esittämisestä asiakkaalle vaikuttaa terapeuttisten keskustelujen kontekstissa hieman jähmeältä ja kapea-alaiselta. Näitä kysymyksiä on hyvä käyttää. Asiakkaiden ongelmiin liittämiä selitysmalleja työntekijä voisi kuitenkin pyrkiä laajemmin ja hyödyllisemmin selvittämään ja ymmärtämään kaikista asiakkaiden keskusteluiden edetessä ilmaisemista merkityksenannoista ja suhtautumistavan kuvauksista. Näin ongelmakuvaukset ja selitysmallit eivät rajoittuisi vain ennalta määriteltyihin raameihin ja niistä keskustelu sopisi luonnollisemmin terapeuttisen keskusteluavun vuorovaikutustapoihin sekä ongelmat tulisivat keskusteluissa paremmin muutostyön kohteiksi.

\section{Tutkimuksen arviointia}

Tässä tutkimuksessa asiakasosallistujien ongelmien tarkastelu perustui luonnollisten terapeuttisten keskustelujen analyysiin. Sen, että keskusteluavun sisältöön ei annettu ohjeita eikä työntekijöillä ollut tietoa tutkimuksessa tarkasteltavista asioista, voi ajatella tuottavan sen, että ongelmista puhuttiin niin kuin ongelmista normaalisti näissä keskusteluissa puhutaan. Vaikka esitetyt löydökset pyrkivät olemaan mahdollisimman aineistolähtöinen konstruktio siitä, miten asiakkaat kuvasivat ongelmiaan, ne ovat tulkintoja ja heijastelevat myös analyysin suorittaneen artikkelin ensimmäisen kirjoittajan mielenkiinnon kohteita sekä herkkyyttä sanallisille ilmauksille. Paikoitellen olisi ollut mielenkiintoista konsultoida asiakasosallistujia ja työntekijöitä tehtyjen havaintojen suhteen.

Ongelmakuvausten luotettavuuteen liittyy haasteita. Tulkit välittivät asiakkaiden ongelmakuvaukset suomeksi. Tulkin tapa kääntää ja hänen käytössään oleva sanasto voi tuoda lisänsä ja vaihtelua kuvauksiin, vaikka tulkkauksen tavoitteena olisikin kääntää asiakkaan puhuma sanatarkasti. Esimerkiksi paljon terapeuttisia keskusteluita kääntävällä tulkilla voi olla ongelmiin liittyvää ammattisanastoa. Tämä voi tuoda kuvauksiin sellaisia ongelmiin liittyviä ammatti-ilmaisuja, jotka eivät täysin vastaa asiakkaan ilmaisuja. Kaikilla tämän tutkimuksen tulkeilla oli aiempaa kokemusta terapeuttisten keskusteluiden tulkkaamisesta. Myös turvapaikanhakija-asiakkaiden ongelmakuvausten paikkansapitävyyteen voi suhtautua jonkinlaisella varauksella. Turvapaikanhakijalla voi olla turvapaikkahakemukseen liittyvä kannustin liioitella tai jopa keksiä ongelmia. Yksikään turvapaikanhakija-asiakkaista ei itse kuitenkaan ollut aloitteellinen esimerkiksi hänen vointiaan koskevan lausunnon laatimisen suhteen, mutta erään asiakkaan lakimies pyysi työntekijää laatimaan sellaisen asiakkaan turvapaikkahakemusta varten.

Asiakkaiden ongelmakuvauksia tarkas- 
teltiin johdannossa esitellyn Kleinmanin ja kumppanien (1978) selitysmalleja tarkastelevan lähestymistavan kautta. Lähestymistapa ei tarjonnut valmista tulkintamallia siihen, mitä voitiin hyväksyä ongelmaa kuvaaviksi ilmauksiksi, vaan tulkintamalli oli rakennettava itse. Taustalla olevan lähestymistavan ja rakennetun tulkintamallin voi ajatella takaavan luotettavamman ja objektiivisemman tutkimusotteen ja analyysin. Ongelmakuvausten tunnistaminen ja ryhmittely ei tästä huolimatta ollut täysin yksiselitteistä. Joidenkin kuvausten tulkinta tietyntyyppiseksi ongelmaksi oli paikoin haastavaa. Tehtyjen tulkintojen säännöllinen arviointi auttoi ja jämäköitti ongelmakuvausten ryhmittelyä, kategorioiden muodostamista ja nimeämistä.

Tutkimuksen kannalta sekä eduksi että haitaksi määriteltävä asia on asiakkaiden pieni määrä. Suurempi asiakasjoukko olisi saattanut tuoda tässä saavutettuihin tuloksiin vielä uusia löydöksiä, mutta samalla pienen joukon etuna oli mahdollisuus tarkastella aineistoa perusteellisesti. Tässä tutkimuksessa perusteellisuus tarkoittaa ennen kaikkea huolellista perehtymistä videotallenteisiin ja niiden litterointia, tallenteiden aktiivista käyttöä ja niihin palaamista analyysissä sekä pyrkimystä kuvata tutkimuksen vaiheet ja tulokset mahdollisimman selvästi ja informatiivisesti. Keskeisintä oli kuitenkin halu ja pyrkimys ymmärtää asiakkaina mukana olleiden ihmisten ongelmia ja elämäntilanteita.

Tulosten merkitys: Tämä tutkimus tuo uutta tietoa Suomessa olevien turvapaikanhakija- ja pakolaisasiakkaiden terapeuttisissa keskusteluissa tekemistä ongelmanmäärittelyistä. Se, miten asiakas hahmottaa ongelmansa, vaikuttaa siihen, mitä hän odottaa työntekijältä ja keskusteluavulta. Se vaikuttaa myös siihen, millaisista keskusteluapukäytännöistä asiakas hyötyy. Tätä tietoa voivat hyödyntää toiminnassaan turvapaikanhakija- ja pakolaisasiakkaiden kanssa terapeuttisia keskusteluita käyvät työntekijät sekä keskusteluapukäytäntöjen kehittäjät ja kouluttajat.

\section{Tiivistelmä}

Tässä tutkimuksessa tarkasteltiin sitä, kuinka kuusi aikuista turvapaikanhakijaja pakolaisasiakasta kuvasivat ongelmiaan terapeuttisissa keskusteluissa. Tutkimuksen kohteena ja tiedon lähteenä olivat asiakkaiden tekemät ja tulkkien suomeksi välittämät ongelmia kuvaavat ilmaukset. Terapeuttisia keskusteluita analysoimalla pyrittiin tavoittamaan ensisijaisesti se, mitä ongelmia asiakkailla on ja lisäksi se, miten nämä ongelmat heihin vaikuttavat ja mikä ongelmat aiheuttaa. Tutkimusmenetelmänä käytettiin aineistolähtöistä laadullista sisällönanalyysia.

Ongelmat koskivat kotimaassa koettua epäoikeudenmukaisuutta ja kotimaassa koettujen traumaattisen kokemusten aiheuttamaa ahdistusta, tulevaisuuteen liittyviä huolia ja pelkoja, huolta läheisten tilanteesta ja siihen liittyvää syyllisyyttä sekä toimijuutta, pystyvyyttä ja elämänhallintaa. Ongelmat aiheutuivat niin kotimaassa koetusta kuin maahantulon jälkeisistä asioista. Ongelma oli yleensä monen tekijän summa. Tämän tutkimuksen löydökset eivät puolla terapeuttiseen keskusteluun mallia, jossa keskityttäisiin kategorisesti vain joko aiemmin kotimaassa tai maahantulon jälkeen koettuihin asioihin.

Ongelmien koostumus vaihteli eri asiakkailla. Huoli kotimaahan palautetuksi joutumisesta tuotti yleisesti pelkoa. Kotimaassa koettu epäoikeudenmukaisuus ja petetyksi tuleminen oli kaikille asiakkaille erityisen raskas asia. Sitä oli vaikeaa tai mahdotonta unohtaa ja antaa anteeksi.

Avainsanat: turvapaikanhakija, pakolainen, terapeuttinen keskustelu, ongelmat, selitysmallit 


\section{Abstract}

Adult asylum seeker and refugee clients' problem definitions in therapeutic conversations.

This study examined how six adult asylum seeker and refugee clients express their problems in therapeutic conversations. This study aimed to find out primarily what kind of problems the clients present, and also how these problems affect them and what caused the problems. The research method was inductive qualitative content analysis.

Therapeutic sessions of the six clients were videotaped and the problem formulations given by the clients and as expressed by an interpreter were extracted as units of analysis. Five problem categories emerged from the analysis: experiences of injustice in home country; anxious ideations originating from past traumatic experiences; fear for the future; worries and feelings of guilt concerning relatives; and problems of self-agency, self-efficacy and life management. Both pre-migration and post-migration factors caused problems. Most often problems were caused by several interacting factors. This study do not support therapeutic conversation formats that focus solely to the issues either related to pre-migration or to postmigration stage.

Different clients had different sets and compositions of problems. Fear of deportation was a common cause for fear to clients. Experiences of injustice and betrayal in the home country caused extreme distress to all clients. Such experiences were hard to forget and hard to forgive.

Key words: asylum seeker, refugee, therapeutic conversation, problems, explanatory models

\section{Authors:}

Olli Snellman, MA, Psychotherapist, Head of Section, Finnish Immigration Service, Reception Unit
Jaakko Seikkula, PhD, Professor, University of Jyväskylä, Department of Psychology, Psychotherapy Training and Research Centre

Jarl Wahlström, PhD, Professor, emeritus, University of Jyväskylä, Department of Psychology, Psychotherapy Training and Research Centre

Katja Kurri, PhD, Researcher, Psychotherapist, University of Jyväskylä, Department of Psychology, Psychotherapy Training and Research Centre

Olli Snellman, FM, psykoterapeutti, tulosalueen johtaja, Maahanmuuttovirasto, Vastaanottoyksikkö

Jaakko Seikkula, PsT, professori, Jyväskylän yliopisto, psykologian laitos, psykoterapian opetus- ja tutkimusklinikka

Jarl Wahlström, PsT, professori (emeritus), Jyväskylän yliopisto, psykologian laitos, psykoterapian opetus- ja tutkimusklinikka

Katja Kurri, PsT, tutkija, psykoterapeutti, Jyväskylän yliopisto, psykologian laitos, psykoterapian opetus- ja tutkimusklinikka

\section{Lähteet}

Alarcón RD (2014) Cultural inroads in DSM-5. World Psychiatry 13, 310-313.

Bandura A (2001) Social cognitive theory: an agentic perspective. Annual Review of Psychology, 52, $1-26$.

Basoglu M, Livanou M, Crnobaric C (2007) Torture vs other cruel, inhuman, and degrading treatment: is the distinction real or apparent? Archives of General Psychiatry 64, 277-285.

Benish SG, Quintana S, Wampold BE (2011) Culturally adapted psychotherapy and the legitimacy of myth: a direct-comparison meta-analysis. Journal of Counseling Psychology 58, 279-289.

Bernardes D, Wright J, Edwards C, Tomkins H, Dlfoz D, Livingstone AG (2010) Asylum seekers' perspectives about their mental health and views on health and social services: contributions for service provision using a mixed-methods approach. International Journal of Migration, Health and Social Care 6, 3-19. 
Bettman JE, Penney D, Clarkson Freeman P, Lecy N (2015) Somali refugee's perception of mental illness. Social Work in Health Care 54, 738-757.

Campbell TA (2007) Psychological assessment, diagnosis, and treatment of torture survivors. Clinical Psychology Review 27, 628-641.

Cloitre M (2015) The “one size fits all” approach to trauma treatment: should we be satisfied? European Journal of Psychotraumatology 6 (27344 doi: 10.3402/ejpt.v6.27344).

Craig T (2010) Mental distress and psychological interventions in refugee populations. Teoksessa: Bhugra D, Craig T, Bhui K (toim.) Mental health of refugees and asylum seekers. Oxford University Press, New York, 9-21.

Douglas A (2010) Identities in transition: living as an asylum seeker. Advances in Psychiatric Treatment 16, 238-244.

Elo S, Kyngäs H (2008) The qualitative content analysis process. Journal of Advanced Nursing 62, 107-115.

Eisenbruch M (1990) The Cultural Bereavement Interview: a new clinical research approach for refugees. Psychiatric Clinics of North America 13, 715-735.

Elsing A (2017) The effect of trauma and discrimination on the psychological well-being among asylum-seekers in Finland. Pro gradu -tutkielma. Psykologian oppiaine, Åbo Akademi.

Fava GA, Sonino N (2010) Psychosomatic medicine: a name to keep. Psychotherapy and Psychosomatics 79, 1-3.

Frank JD (1986) Psychotherapy - the transformation of meanings: discussion paper. Journal of the Royal Society of Medicine 79, 341-346.

Haavikko A, Bremer L (2009) Ulkoisesti erilaisia, sisäisesti samanlaisia. Opas mielenterveystyöhön yli kulttuurirajojen. Suomen Mielenterveysseura, SMS-Tuotanto Oy, Helsinki.

Helman CG (2004) Culture, Health, and Illness. 4th edition. Hodder Arnold, London.

Hinton DE, Jalal B (2014) Guidelines for the implementation of culturally sensitive cognitive behavioural therapy among refugees and in global contexts. Intervention 12, 72-93.

Hinton DE, Kirmayer LJ (2013) Local responses to trauma: symptom, affect, and healing. Transcultural Psychiatry 50, 607-621.

Iversen VC, Berg JE, Vaaler AE (2010) Expectations of the future: immigrant, asylum seeker, or refugee - does it matter? Journal of Psychiatric Intensive Care 6, 23-30.

Kirmayer LJ (2005) Culture, context and experience in psychiatric diagnosis. Psychopathology 38, 192-196.
Kleinman A, Benson P (2006) Anthropology in the clinic: the problem of cultural competency and how to fix it. Plos Medicine 3 (e294. doi:10.1371/journal.pmed.0030294).

Kleinman A, Eisenberg L, Good B (1978) Culture, illness, and care: clinical lessons from anthropologic and cross-cultural research. Annals of Internal Medicine 88, 251-258.

Lewis- Fernández R, Aggarwal NK, Hinton L, Hinton DE, Kirmayer LJ (toim.) (2016) DSM-5 ${ }^{\circledR}$ Handbook on the Cultural Formulation Interview. American Psychiatric Association Publishing, Arlington.

Maier T, Straub M (2011) "My head is like a bag full of rubbish": concepts of illness and treatment expectations in traumatized migrants. Qualitative Health Research 21, 233-248.

Mayring P (2000) Qualitative content analysis. Forum: Qualitative Social Research 1(2), Art 20 (http:// www.qualitative-research.net/index.php/fqs/article/viewArticle/1089/2385).

Miller KE, Kulkarni M, Kushner H (2006) Beyond trauma-focused psychiatric epidemiology: bridging research and practice with war-affected populations. American Journal of Orthopsychiatry 76, 409-422.

Murray KE, Davidson GR, Schweitzer RD (2010) Review of refugee mental health interventions following resettlement: best practices and recommendations. American Journal of Orthopsychiatry $80,576-585$.

Nickerson A, Schnyder U, Bryant RA, Schick M, Mueller J, Morina N (2015) Moral injury in traumatized refugees. Psychotherapy and Psychosomatics 84, 122-123.

Papadopoulos RK (2007) Refugees, trauma and Adversity-Activated Development. European Journal of Psychotherapy \&t Counselling 9, 301-312.

Patel N, Kellezi B, Williams ACDC (2014) Psychological, social and welfare interventions for psychological health and well-being of torture survivors. Cochrane Database of Systematic Reviews 2014, issue 11 (DOI: 10.1002/14651858.CD009317.pub2).

Ryan DA, Benson CA, Dooley BA (2008) Psychological distress and the asylum process: a longitudinal study of forced migrants in Ireland. The Journal of Nervous and Mental Disease 196, 37-45.

Smith JM, Alloy LB (2009) A roadmap to rumination: a review of the definition, assessment and conceptualization of this multifaceted construct. Clinical Psychology Review 29, 116-128.

Snellman 0, Seikkula J, Wahlström J, Kurri K (2014) Aikuisten turvapaikanhakijoiden ja pakolaisten mielenterveyden ja psyykkisten ongelmien erityispiirteet. Sosiaalilääketieteellinen aikakauslehti 51, 203-222. 
Strijk PJM, van Meijel P, Gamel CJ (2011) Health and social needs of traumatized refugees and asylum seekers: an exploratory study. Perspectives in Psychiatric Care 47, 48-55.

Ting-Toomey S, Kurogi A (1998) Facework competence in intercultural conflict: an updated facenegotiation theory. Intercultural Journal of Intercultural Relations 22, 187-225.

Tribe R, Lane P (2009) Working with interpreters across language and culture in mental health. Journal of Mental Health 18, 233-241.

Wahlström J (2006) The narrative metaphor and the quest for integration in psychotherapy. Teoksessa: 0` Leary E, Murphy M (toim.) New approaches to integration in psychotherapy. Routledge, New York, 38-49.
Wampold BE (2007) Psychotherapy: the humanistic (and effective) treatment. American Psychologist 62, 855-873.

Weiss MG (1997) Explanatory Model Interview Catalogue (EMIC): framework for comparative study of illness experience. Transcultural Psychiatry 34, 235-263.

Weiss MG, Somma D (2007) Explanatory models in psychiatry. Teoksessa: Bhugra D, Bhui K (toim.) Textbook of Cultural Psychiatry. Cambridge University Press, Cambridge UK, 127-140.

\section{NEURO LINGUISTIC PROGRAMMING - NLP KOULUTUSPÄIVIÄ KUNTOUTTAJILLE JA KUNTOUTUJILLE}

- Tavoitteet ja tulevaisuuden kuvat kuntoutumisessa 20.10.2017, 1 pv

- Kehomieli - alitajunta yhteistyökumppanina 24.11.2017, 1 pv

- Kuntoutujan maailmankuva kuntoutumisen taustana 16.2.2018, 1 pv

- Uskomukset osana kuntoutujaa 23.3.2018, 1 pv

Koulutuspäivät toimivat itsenäisinä, mutta täydentävät toisiaan. Yksi koulutuspäivä $150 € /$ hlö (sis. alv). Ilmoittaudu valinnaiseen kahteen päivään, ja maksa yhteensä $240 € /$ hlö (sis. alv), kolme päivää $340 €$ /hlö (sis. alv) tai osallistu kaikkiin neljään, hintaan $420 € /$ hlö (sis. alv).

Lisätietoja ja ilmoittautuminen www.koivulaukka.com kyselyt henna.laukka@koivulaukka.com 